\title{
INDUCTION OF MUTATION IN NEUROSPORA CRASSA WITH ULTRAVIOLET RADIATION AND EVALUATION OF CELLULASE AND XYLANASE ACTIVITIES
}

\author{
Tahsina Rahim, Apurba lal Ray ${ }^{*}$, Salina Parvin Beauty \\ AND Donald James Gomes ${ }^{1}$
}

Department of Botany, University of Dhaka, Dhaka-1000, Bangladesh

Key words: Neurospora crassa, Mutants, Cellulase activity, Xylanase activity

\begin{abstract}
Wild Neurospora crassa (Ema) showed highest cellulase activity (0.063 IU) followed by mutants trp $101(0.055)$ and leu 299 (0.024). In case of xylanase activity, mutant leu 299 showed highest $(0.323)$ followed by wild (0.310) and mutant trp 101 (0.259).

Fungi play a major part in the conversion of lignocellulosic material to essential metabolites for growth (Benoliel et al. 2005) and recycling of cellulose (Lynd et al. 2002). Neurospora crassa (Ascomycetes), a non-pathogenic filamentous fungus, is of particular interest to biologists because of its use in the study of genetic and metabolic pathways. Sunna and Antranikian (1997) reported that cellulase and xylanase enzymes may be used in fruit juice clarification and vegetable oil extraction. In this study, an attempt was taken to produce mutants of $N$. crassa (Ema) for evaluation of cellulase and xylanase activities compared to the wild type and also to evaluate whether mutation has any considerable effect for the production of such enzymes.

UV radiation of $254 \mathrm{~nm}$ was used for induction of mutation in $N$. crassa (Ema, 5297) using filtration enrichment method (Catcheside 1949). UV ray was passed through a small Petri dish containing suspension of fresh Ema conidia at a distance of $15 \mathrm{~cm}$ for $45 \mathrm{sec}$. Vogel's minimal medium (Vogel 1956) was used for culturing $N$. crassa in the test tube and Sorbose minimal medium (SM) was used for single colony isolation. The UV ray induced isolates of $N$. crassa were tested for growth on SM plates. Those did not grow on SM plate were further tested on SM supplemented plates separately with adenine, arginine, histidine, leucine, lysine and tryptophan to classify them into biochemical mutants.

For the study of enzyme activities, wild and mutants of $N$. crassa were grown on VM liquid medium (supplemented for biochemical mutants) separately in which the glucose was replaced by carboxymethylcellulose (CMC) and xylan at $0.5 \%(\mathrm{w} / \mathrm{v})$ concentration. The fungi were incubated at $30^{\circ} \mathrm{C}$ for 3 days in static condition. The mycelia and other non-soluble material in the culture filtrates were separated by centrifugation at $15,000 \mathrm{rpm}$ for $5 \mathrm{~min}$. The clear supernatants were used for enzyme assays $(0.2 \mathrm{ml}$ supernatant with $1.8 \mathrm{ml}$ substrate in each case). For this purpose, standard curves of reducing sugar for CMCase and xylanase were prepared. Reducing sugars were determined by measuring the absorbance at $540 \mathrm{~nm}$. Hydrolytic activity was calculated by measuring the amount of reducing sugars released from CMC and xylan. The amount of reducing sugar produced was measured by the DNS method (Miller 1959) using glucose and xylose as standards for CMCase and xylanase activities, respectively. One unit of enzyme activity was defined as the amount of enzyme required to produce $1 \mu$ mol reducing sugar equivalent per minute under the assay conditions.

UV ray induced biochemical mutants (Table 1) were designated as trp 101 (tryptophan) and leu 299 (leucine) and were used for extracellular cellulase (CMCase) and xylanase production in submerged cultures.
\end{abstract}

*Corresponding author. E-mail: apurba.anirban@gmail.com ${ }^{1}$ Department of Microbiology, University of Dhaka, Dhaka-1000, Bangladesh. 
Table 1. UV ray induced biochemical mutants of Neurospora crassa.

\begin{tabular}{lccccccc}
\hline $\begin{array}{l}\text { Culture } \\
\text { no. }\end{array}$ & $\begin{array}{c}\mathrm{SM}+ \\
\text { adenine }\end{array}$ & $\begin{array}{c}\mathrm{SM}+ \\
\text { arginine }\end{array}$ & $\begin{array}{c}\mathrm{SM}+ \\
\text { histidine }\end{array}$ & $\begin{array}{c}\mathrm{SM}+ \\
\text { lysine }\end{array}$ & $\begin{array}{c}\mathrm{SM}+ \\
\text { leucine }\end{array}$ & $\begin{array}{c}\mathrm{SM}+ \\
\text { tryptophan }\end{array}$ & $\begin{array}{c}\text { Inference } \\
\text { of mutants }\end{array}$ \\
\hline 101 & $\bigcirc$ & $\bigcirc$ & $\bigcirc$ & $\bigcirc$ & $\bigcirc$ & $\bigcirc$ & tryptophan \\
299 & $\bigcirc$ & 0 & $\bigcirc$ & $\bigcirc$ & $\bullet$ & $\bigcirc$ & leucine \\
\hline
\end{tabular}

Enzyme activities were calculated by the amount of reducing sugar obtained from standard curve prepared for CMCase and xylanase. It was found that $N$. crassa secretes cellulases (CMCase) to the culture supernatant. The cultures grown on CMC yielded detectable activities. Wild N. crassa (Ema) showed highest cellulase activity, mutant trp 101 showed nearest and mutant leu 299 showed lowest activity (Table 2). But cellulase production of wild and mutants is lower than wild as well as UV ray induced anthranilic acid mutants of $N$. crassa as reported earlier by Rahim (2001). In case of xylanase, mutant leu 299 showed highest, Ema showed nearest and trp 101 showed lowest activity (Table 2). The xylanase activity of leu 299 is higher than the xylanase activity of UV ray induced 8 anthranilic acid mutants of $N$. crassa in static culture (highest $0.30 \mathrm{IU}$ ) as reported by Rahim (2001).

Table 2. Mean cellulase and xylanase activities of wild and mutants of Neurospora crassa. $\mathrm{n}=3$, $\pm=$ standard deviation.

\begin{tabular}{lcc}
\hline $\begin{array}{l}\text { Name \& number of } \\
\text { wild \& mutants }\end{array}$ & $\begin{array}{c}\text { CMCase } \\
(\mathrm{IU})\end{array}$ & $\begin{array}{c}\text { Xylanase } \\
(\mathrm{IU})\end{array}$ \\
\hline Ema & $0.063 \pm 0.003$ & $0.310 \pm 0.003$ \\
leu 299 & $0.024 \pm 0.003$ & $0.323 \pm 0.005$ \\
trp 101 & $0.055 \pm 0.004$ & $0.259 \pm 0.005$ \\
\hline
\end{tabular}

The study indicated that $N$. crassa is able to grow in media containing cellulose or xylan as the sole carbon source. Besides, these findings revealed that mutation has no considerable effect for the production of cellulase and xylanase enzymes. It was reported that indigenous tribesman in Brazil use Neurospora to process cassava in preparing fermented beverage (Park et al.1982). As $N$. crassa is a non-pathogenic fungus with vigorous growth, it may also be used to produce such enzymes in large scale.

\section{References}

Benoliel B., F.B.M. Arraes, V.C. Reis, S.J.L. Siqueira, N. S. Parachin and F.A.G. Torres. 2005. Hydrolytic enzymes in Paracoccidioides brasiliensis- ecological aspects. Genet. Mol. Res. 4(2): 450-461.

Catcheside D.G. 1949. Isolation of nutritional mutants of Neurospora crassa by filtration enrichment. Gen. Microbiol. 11: 34.

Lynd L.R., P.J. Weimer, W.H. Van Zyl and I.S. Pretorius. 2002. Microbial cellulose utilization: fundamentals and biotechnology. Microbiol. Mol. Biol. Rev. 66: 506-577.

Miller G.L. 1959. Use of dinitrosalicylic acid reagent for determination of reducing sugars. Anal. Chem. 31: 426-428.

Park Y.K., C.T. Zenin, S. Ueda, C.O. Martins and J.P.M. Neto. 1982. Microflora in Beiju and their biochemical characteristics. J. Ferment. Technol. 60:1-40. 
Rahim T. 2001. Genetical and biochemical investigations and protoplast fusion of anthranilic acid mutants of Neurospora crassa. Ph.D. thesis. Department of Botany, Univ. Dhaka, Dhaka. 152 pp.

Sunna A. and G. Antranikian. 1997. Xylanolytic enzymes from fungi and bacteria. Crit. Rev. Biotech. 17(1): 39-67.

Vogel H.J. 1956. A convenient growth medium for Neurospora crassa. Microbial Genet. Bull. 13: 42- 43.

(Manuscript received on 17 March, 2009; revised on 15 September, 2009) 